\title{
Desterritorialização e forma literária
}

Literatura brasileira contemporânea e experiência urbana

\author{
Flora Süssekind
}

predominantemente urbana a imaginação literária brasileira nas últimas décadas. $\mathrm{O}$ que se evidencia até mesmo em relatos de forte teor regional (como os de Raimundo Carrero), em histórias de migração e inadaptação social (como em As Mulheres de Tijucopapo, de Marilene Felinto), ou nas quais rastros da experiência rural se justapõem por vezes a um cotidiano citadino (como em alguns dos contos de Angu de Sangue, de Marcelino Freire). Essa dominância parecendo apontar tanto para o fato de a população brasileira ter se tornado sobretudo urbana nesse período, com apenas $30 \%$ permanecendo no campo, quanto para uma reconfiguração artística das tensões entre localismo e cosmopolitismo, rural e urbano. Articulaçôes que, fundamentais para a autoconscientização cultural, inclusive para sua diferenciação regional, no país, se veriam marcadas crescentemente pela hipertrofia de um dos pólos, por um desdobramento das mediações entre organização social urbana e forma artística, processo no qual duplicação e representabilida- de não têm significado necessariamente complexificação dos recursos formais, da prática literária e da experiência histórica recente. Muitas vezes essa complexificação resultando não exatamente de representações explícitas, documentais, do urbano, mas da produção de espaços não representacionais e de zonas liminares, ambivalentes, transicionais, da subjetividade.

Por isso optou-se aqui pelo exame mais detido de alguns exemplos da produção poética brasileira e não das letras de rap ou funk, com seu registro do cotidiano violento e excludente nas periferias das grandes cidades do país, ou da prosa recente, na qual se multiplicam os testemunhos diretos, as histórias de vida, os percursos e contrastes urbanos. E de que são exemplares obras como o romance Capão Pecado, de Férrez, escrito em linguagem propositadamente de gueto, com material autobiográfico, por um ex-padeiro, filho de um motorista de ônibus, morador do bairro Capão Redondo, da zona sul de São Paulo. Ou como as histórias de presidiários reunidas, em 2000, no volume

Flora Süssekind é pesquisadora da Fundação Casa de Rui Barbosa e professora do Departamento de Teoria do Teatro da UNIRIO. Este ensaio, que procura retrabalhar, em perspectiva mais ampla, alguns artigos publicados originalmente como colaboração mensal ao caderno Idéias, do Jornal do Brasil, foi apresentado, parcialmente, em encontro realizado em março de 2001, a convite de César Braga Pinto e do Departamento de Português e Espanhol da Universidade de Rutgers e, em versão ampliada, em seminário realizado em 21 de maio de 2002 no Centre for Brazilian Studies em Oxford, a convite de Leslie Bethell. 
Letras de Liberdade; as memórias de rua, como o livro Por que não dancei, de uma ex-menina de rua, Esmeralda do Carmo Ortiz; ou os itinerários homoeróticos, como os de José Carlos Honório. Todos estes textos, de algum modo, evidenciando o neodocumentalismo intensificado na ficção brasileira contemporânea, marcada ora por uma espécie de imbricação entre o etnográfico e o ficcional (de que são exemplares tanto um romance como Cidade de Deus, de Paulo Lins, quanto o conjunto de relatos e tramas fragmentárias do cotidiano de rua de que se compõe Vozes do Meio-Fio, dos antropólogos Hélio R. S. Silva e Cláudia Milito), ora por um registro duplo, no qual se espelham fotos e relatos, dando lugar a uma sucessão de livros ilustrados, que se converteriam, nos últimos anos, quase em gênero-modelo dessa imposição representacional.

\section{Reterritorializações e desterritorializações}

Exemplares desse espelhamento mútuo entre o fotográfico e o narrativo, entre a ilustração e as tramas testemunhais, são livros como Capão Pecado, cujo relato se faz acompanhar de dois cadernos de fotos profissionais e caseiras que parecem materializar a geografia romanesca, e Estação Carandiru, testemunho de Dráuzio Varella sobre o seu trabalho voluntário como médico na Casa de Detenção de São Paulo, ao qual se anexou um vasto arquivo iconográfico, tirado do seu acervo pessoal, de coleções particulares e dos arquivos de jornal, à guisa de suplemento, de referendum fotojornalístico ao registro narrativo.

Os dois livros, de importância documental inegável, têm estrutura semelhante, baseada na produção de uma relação de similaridade entre as imagens fotográficas de um segmento da periferia urbana, em Capão Pecado, e de um presídio brasileiro, em Estação Carandiru, e um texto enxuto, com frases curtas, dicção paradoxalmente leve, de crônica, cheio de apelidos, expressões de gueto, ditados e exemplos de violência verbal, muitos diálogos e um verdadeiro exercício tipológico, tendo por base, de um lado, a população carcerária, de outro, os destinos e o cotidiano dos moradores de uma das regiōes mais pobres de São Paulo. Nos dois casos parece caber à fotografia o fornecimento de prova de evidência ao narrado. $\mathrm{O}$ que, se, por um lado, empresta a ele visibilidade e reconhecimento imediatos; por outro lado, produz uma relação de dependência discursiva evidente do modo narrativo com relação à sua contraparte visual.

Essa geminação entre foto e relato se, à primeira vista, parece produzir uma aproximação entre o leitor e a matéria urbana enfocada, e uma materialização literária da trama citadina, ganha sentido distinto quando se observa que a operação fundamental, nesses relatos ilustrados, é justamente a colocação entre parênteses dos recursos narrativos, como possibilidade de ampliação, reforçada pelos cadernos de fotos e por uma escrita parajornalística, do campo de visibilidade contextual. A neutralização do processo narrativo, em prol de um inventário imagético, de uma imposição documental, tendendo, todavia, tanto à reprodução de tipologias e conceituações correntes, estandardizadas ${ }^{1}$, com relação a essas populações, quanto ao congelamento da perspectiva (à primeira vista, aproximada) de observação numa presentificação restritiva, estática, fundamentada no modelo da coleção, e não na experiência histórica propriamente dita.

Esta imposição representacional pode ser percebida, mas de modo diverso, em livros

1 O que explica, em parte, a quantidade de semanas de permanência ininterrupta de Estação Carandiru na lista de best-sellers das revistas e jornais brasileiros de maior circulação. 
como Angu de Sangue, de Marcelino Freire, no qual as imagens fotográficas propositadamente desrealizadas cumprem, no entanto, função ilustrativa, ou em Treze, de Nélson de Oliveira, ilustrado com fotos extraídas do arquivo de registros de admissão de um hospício vitoriano inglês. Nesses livros o aspecto abstratizado ou grotesco das imagens serve também de reduplicação, mas de reduplicação perversa, não é difícil perceber. Pela desrealização, no primeiro caso, e pelo desajuste histórico da série de retratos oitocentistas utilizada em Treze, sobretudo tendo em vista os quadros e tipos urbanos insólitos, mas cotidianos, desses contos.

O reiterado movimento de reduplicação entre texto e imagem, relato e ilustração (ao lado de uma espécie de exigência de adaptabilidade potencial ao cinema ou à televisão) funcionando, em geral, ao contrário, nesses livros ilustrados (como os de Férrez e Dráuzio Varella), nesses livros-roteiros potenciais (Cidade de Deus, por exemplo), como afirmação da própria fidedignidade por meio do deslocamento da atenção do leitor do processo narrativo em direção a imagens que se apresentem como vias diretas de acesso ao contexto, ao referente extraliterário desses testemunhos e ficçôes. Mas o que se observa é que nessa aparente captura documental do referente urbano, para aproximá-lo do leitor, com freqüência, quando se observam essas imagens, verifica-se que operam com clichês, com reimpressões de um repertório previsível de figuras e situações citadinas, que, ao contrário do que se afigura à primeira vista nessas obras, acentuam (ao invés de criticá-las) as distinções sociais já demarcadas, com precisão, no cotidiano. A ampliação da área de visibilidade urbana, ao contrário do que sugere, então, a rigor, a inclusão do catálogo fotográfico, parecendo corresponder, em parte, nesses casos, a uma restrição narrativa e crítica, a uma reafirmação da distância entre observador e matéria documentada, a um controle e uma imobilização da perspectiva histórica.

Não é propriamente o que ocorre em Tre$z e$, como já se assinalou, pois aí o simples fato de se recorrer a um arquivo fotográfico-hospitalar vitoriano já produz tensão evidente entre imagem fotográfica anacrônica e conto atual. Não é também o que acontece em "Minha História Dele", outro texto ilustrado, desta vez de Valêncio Xavier, e que foi publicado originalmente, no primeiro número da revista "Ficçôes", em 1998. Aí, a rigor, só se dispõe mesmo de quatro imagens de um homem coreano, morador de rua em Curitiba, que, à maneira de um homem-sanduíche, traz a própria história manuscrita e pendurada no corpo.

Neste caso, a reduplicação entre texto e imagem parecendo chegar a um tal extremo que mesmo o relato e a escrita a mão nele empregada são elementos extraídos dos cartazes pendurados ao corpo do andarilho citadino, o relato propriamente dito achando-se aparentemente inscrito nas fotos. E a alternância entre proximidade e distância, perceptível no contraste interno a cada um dos dois pares de fotos, a rigor quase idênticas, que constituem o conto, temporalizando a observação do pedinte e assinalando, por meio de um jogo pronominal irônico ("Minha História Dele") presente no título, a ligação entre observador e morador de rua.

O conto de Valêncio Xavier aproxima-se, nesse sentido, de um dos topoi de maior expansão no imaginário urbano brasileiro - o dos "encontros inesperados” entre pessoas díspares -, definidos por Ismail Xavier como "experiências pontuais, marcadas por certa singularidade", oferecidas pela "migração" ou pelo "espaço da cidade" (Xavier, 2000, p. 110-1; 116-7; ver, também, Conti, 2000, p. 8-9). E que teriam exemplos cinematográficos recentes, como assinala o crítico paulista, no encontro fictício da atriz Sarah Bernhardt com as três matutas do interior de Minas Gerais no filme "Amélia", de Ana Carolina; do menino Josué com a exprofessora Dora em "Central do Brasil", de Walter Salles Jr.; de meninos pobres, por acaso armados, com um americano e sua família em "Como nascem os anjos", de Murilo Salles; do foragido da cadeia com a moça de classe média na noite de Réveillon em "O primeiro dia", de 
Walter Salles e Daniela Thomas. Encontros que, em diálogo com os quadros urbanos baudelairianos que muitas vezes lhes servem de fonte, se manifestariam igualmente na poesia brasileira contemporânea.

É o caso de "Spiritus ubi vult spirat", poema de Sebastião Uchoa Leite no qual o sujeito, atravessando a Av. Presidente Vargas, se depara "com uma sobrevivente" de saia erguida enquanto todos os demais passam, indiferentes. Ou do encontro com o morador de rua em "03/ 11/97”, de Régis Bonvicino, de que se fala, a certa altura: "Ele poderia subitamente ter sacado a faca, na calçada, disseram". Há registro semelhante no poema "Em sua cidade", de Duda Machado, no qual, em meio à paisagem baiana, meninos e mendigos circulam entre vendedores e cestos de frutas, enquanto, da perspectiva do sujeito do poema, "um dispositivo íntimo,/ destinado a anular/ toda presença,/ interceptava o contato/ e o retraía, ainda tenro,/ à raiz do pânico".

Mas do retraimento, se passa, no poema de Duda Machado, à respiração, a um "voltar a si" que "reerguia o mundo" para "além de qualquer tentativa/ de fuga ou domínio". E, voltando ao conto "Minha História Dele", de Valêncio Xavier, aí o extremo realismo das fotos, assim como sua reduplicação, ao lado do fato de se apresentar o texto como parte dos dizeres das tabuletas penduradas no pedinte, também são elementos que parecem destravar o contato nesse registro de encontro urbano. E que parecem funcionar como recurso quase imediato de desperspectivização, de trânsito - e não separação - entre sujeito e objeto, entre narrador invisível e imagem fotográfica de um morador de rua. $\mathrm{O}$ que provoca o apagamento tanto de possível retração subjetiva, quanto de uma relação meramente ilustrativa entre texto e foto, pois a própria sucessão de imagens (incluindo as textuais) é que é produtora de uma narratividade conflituosa, desconfortável, movida pelo encontro com o sem-teto e pelos recortes e acréscimos visuais impostos ao texto-tabuleta que o cobre. E pelos exercícios de afastamento e apro- ximação com relação a este quadro urbano cuja violência implícita, ao contrário da segregação dominante na experiência citadina cotidiana, resultaria, aí, numa espécie de desdobramento da apreensão visual, na produção de uma perspectiva dupla (minha/dele) para o relato.

Pois, neste caso, o sem-teto também parece observar o seu observador textual, além de a reprodução em bruto da sua tabuleta escrita a mão também atribuir materialmente a ele função narrativa. Trânsito que se tornaria estrutural no trabalho de um escritor como João Gilberto Noll, cujos narradores invariavelmente deambulatórios, desabrigados, refiguram ficcionalmente a experiência urbana dos sem-teto, as diversas estratégias de sobrevivência na rua. E não é à toa que um dos títulos de suas novelas envolveria uma espécie de auto-classificação narratorial errática - "quieto animal da esquina” - que parece sintetizar esse trânsito entre experiência ficcional e urbana, entre modos de deambulação.

Mas o mais habitual mesmo nessa literatura urbana não é o desdobramento de perspectiva, e sim a catalogação patológico-criminal (ironizada na coleção de fisionomias de Treze) de lugares e tipos humanos, o temor da heterogeneidade social, a reiterada criminalização das divisões sociais, o reforço a uma espécie de paranóia urbana endêmica a que respondem as classes médias e as elites financeiras com movimentos de auto-segregação em enclaves habitacionais, shopping-centers e centros empresariais de freqüência controlada, e com o investimento em formas de segurança particular, guardacostas, vigias, alarmes, cercamentos, privatizações de ruas e praças. Explicando-se, assim, em parte, em sintonia com essa insegurança generalizada, a popularização das histórias de crime e da literatura policial no Brasil dos anos 19801990, de que é exemplar a ficção de Rubem Fonseca.

Pois é fundamentalmente um imaginário do medo e da violência que organiza a paisagem urbana dominante na literatura brasileira contemporânea. O que é também parcialmente 
explicável em relação direta com o crescimento das taxas de crime violento nas grandes cidades do país nos anos 1980-1990, com o fortalecimento do crime organizado, com a ineficiência da polícia e do sistema judiciário no exercício da segurança pública e da justiça, com o aumento de visibilidade do contingente populacional em situação de pobreza absoluta que perambula pelas grandes cidades, expulso tanto das favelas, quanto dos enclaves fortificados de classe média, com uma espécie de generalização da violência, que abrange do trânsito automobilístico às relações familiares, dos estádios de futebol aos justiceiros e matadores profissionais e ao exercício privado da segurança e da vingança. $\mathrm{O}$ que por vezes, no entanto, aproxima também a ficção policial dos "discursos do medo", da proliferação das "falas do crime" (Caldeira, 2000, p. 9), para empregar expressões utilizadas por Teresa Caldeira em Cidade de Muros, estudo sobre "crime, segregação e cidadania em São Paulo", por meio dos quais se reorganizam simbolicamente não só os pânicos urbanos, mas igualmente os temores de perda de posição social e propriedade, a instabilidade financeira, dilemas internos e questôes sociais estruturais à sociedade brasileira.

Essa criminalização do social parece ter se acentuado exatamente no período de redemocratização política do país. E parece operar discursivamente por meio de classificações rígidas, estereótipos, segregações, recorrentes não apenas no noticiário policial jornalístico, nas histórias individuais sobre assaltos, práticas variadas de violência, homicídios, mas, igualmente, na produção literária dos últimos decênios, que reterritorializa, em vocabulário criminal conhecido, "um novo padrão de organização das diferenças sociais no espaço urbano" (Caldeira,
2000, p. 9), um processo desestabilizante de mudança social que afeta as relaçõos estabelecidas de poder, as hierarquias sociais e o exercício da cidadania.

Não se limitam, no entanto, a operações literárias de reterritorialização etnográfica ou criminal essas tematizações urbanas na produção cultural recente do país. Funcionando, nesse sentido, como interlocutores particularmente críticos de uma experiência citadina de violência, instabilidade e segregação alguns dos processos de desfiguração e desterritorialização ${ }^{2}$, estruturais à literatura brasileira contemporânea, que se passam a examinar em seguida.

Não que a desfiguração seja via exclusiva de diálogo crítico entre forma literária e experiência urbana no Brasil contemporâneo. Bastando lembrar, nesse sentido, como mais um contra-exemplo, o livro Sob a Noite Física, de Carlito Azevedo. Neste caso, uma imagem urbana em especial - a do lixo espalhado pelo Rio de Janeiro - converte-se em indicação privilegiada de leitura. Desde o poema inicial do livro, no qual se anuncia "o último vôo da varejeira" a partir do "lixo da esquina", passando pelos textos iniciais de quase todas as seçôes, com suas referências a "depósito de lixo", "ao latão de lixo da esquina", a latas de lixo que, "no breu convulso", se assemelham a vultos, à "dor no entressonho" que, "com seu grão de lixo, se infiltra" no corpo. Transformando-se o externo em interno, o lixo, a rigor aspecto do espaço físico citadino, em quase habitante, vulto animado, e em elemento constitutivo do eu lírico. Incorporação por meio da qual um aspecto da paisagem noturna empresta materialidade física dolorosa à figuração corporal do sujeito.

Mas se, no caso do livro de 1996 de Carlito Azevedo, a tematização do urbano se faz,

2 Emprego aqui expressão cunhada, como se sabe, por Gilles Deleuze e Félix Guattari em O Anti-Édipo, e retrabalhada por Fredric Jameson em The Cultural Turn, mas submetida a desdobramentos bastante distintos e a um contexto particular, o das relaçôes entre imaginário literário urbano e processo cultural no Brasil contemporâneo. 
nessas imagens do lixo, por aproximação, por incorporação, esse movimento parece apontar simultaneamente, no entanto, para um "formigamento", uma experiência corporal dolorosa próxima dos mecanismos de desfiguração, das exposições cruentas de corpos, por meio dos quais se tem constituído, com freqüência via horror, a subjetividade na produção cultural brasileira sobretudo desde os anos 1980 .

\section{Subjetividade e horror}

Não é, de fato, difícil perceber um rastro de Guignol na vida cultural brasileira das últimas décadas. Passando das minuciosas descrições dos corpos e assassinatos de mulheres em Acqua Toffana, de Patrícia Melo, à exumação dos cadáveres do pai e de um irmão relatada no conto "A Carne e os Ossos", de O Buraco na Parede, de Rubem Fonseca. Da exposição de um corpo de criança atravessado por uma estaca de madeira, presente numa das fotos de C. A. Silva, exibidas na Galeria da Funarte em 1996, à "menina de rua morta nua" do relato, cheio de retratos e registros policiais, de Valêncio Xavier. Ou aos "dentes do apodrecimento" que "engolem o corpo" num dos poemas de Cheiro Forte, de Silviano Santiago, aos vivos vorazes, do poema "Os Vivos", de Ferreira Gullar, que, "glutôes ferozes", "devoram os outros vivos" e "até dos mortos comem/ carnes ossos vozes". Da perna amputada do narrador do romance Hotel Atlântico, de João Gilberto Noll, ao sujeito "todo em fios" - preso a uma cama de hospital na seção "Incertezas" do livro Ficção Vida, de Sebastião Uchoa Leite.

Referência guignolesca também particularmente acentuada, e, ao que parece, metódica, na produção teatral recente. Passando de "O Livro de Jó" e "Apocalipse”, de Antônio Araújo e do grupo "Teatro da Vertigem", de "As Bacantes", na versão de José Celso Martinez Correia, às descrições e exposições de tortura que constituem "Bugiaria", de Moacir Chaves, aos espetáculos de Gerald Thomas dos anos 1990 de modo geral. Nowhere Man, por exemplo, deste último, já se iniciava com o seu "Fausto" em trajes meio ensangüentados, tendo um pseudocadáver feminino como interlocutor. E, na sua segunda montagem do Quartett, de Heiner Müller, os dois personagens, também com roupas e facões sujos de sangue, circulavam entre enormes pedaços de carne suspensos e um cenário em que escorriam manchas sanguinolentas por todos os lados. Dado de horror que tem estado presente regularmente no seu teatro. Basta lembrar ainda os pedaços de corpos espalhados pelo chão em Matogrosso ou o coração e a cabeça arrancados às duas figuras femininas de The Flash and Crash Days.

O que parece ter ocorrido, porém, se nos fixamos, por exemplo, em algumas das montagens de Gerald Thomas dos anos 1990, foi um aumento de ênfase nesses sinais de sangue, mutilação, tormento físico, acompanhado da explicitação auto-irônica de se estar trabalhando, aí, muitas vezes, com alguns dos truques mais característicos do gênero "Grand Guignol”. Desde as facas com pontas retráteis às mesas que ocultam corpos, das gradações de cor e variações de composição e textura do sangue fictício ao despedaçamento físico da atriz Fernanda Torres em The Flash and Crash Days, à sua cabeça arrancada do corpo em O Império das Meias Verdades, ou aos corpos atravessados por setas (como o de Fernanda Montenegro em The Flash and Crash Days) e facões (como na abertura de Nowhere Man).

Se o teatro do Grand Guignol, de grande popularidade de fins do século XIX até o período entre-guerras, ancorava seu efeito cênico no fait divers médico ou criminal e num misto de interpretação e hábil exercício de mágica, o que parece torná-lo especialmente curioso é, de um lado, a sua transformação de inovações técnicas (dos truques de iluminação e áudio aos telefones, automóveis e novidades médicas) em elementos dramáticos, e, de outro, a apresentação de uma espécie de pastiche de horror não apenas da experiência moderna do corpo e da própria subjetividade como instáveis, fragmenta- 
dos, mas, sobretudo, da figuração do corpo como "corpo em pedaços", dominante, mas com variações de sentido, na arte moderna e pós-moderna. E há, sem dúvida, nesse sentido, nesse Guignol brasileiro recente, um diálogo com a extrema crueldade com o corpo presente em alguns exemplos da body art contemporânea, com a figuração atormentada, a fragmentação paradigmática e polivalente na produção artística do século XX, das bocas de Bruce Nauman ou Francis Bacon, aos olhos imensos, pedaços de pernas, mãos, aos desmembramentos diversos operados por Louise Bourgeois, das fotos de fragmentos de cadáveres de Andres Serrano às supressões corporais na obra de Samuel Beckett.

Talvez, no entanto, haja outras fontes, não exclusivamente plásticas ou artísticas, para esse rastro guignolesco. E algumas delas talvez possam ser sugeridas, como no teatro do "Grand Guignol” propriamente dito, por uma simples consulta ao noticiário jornalístico do país em fins dos anos 1990. Por exemplo à sucessão de fotos de ossadas e imagens de arquivo de antigos retratos e de corpos executados dos militantes de esquerda, dos desaparecidos políticos brasileiros dos anos de autoritarismo militar, que invadiram as páginas de jornal, no último decênio do século XX, por conta do aparecimento de novas informaçôes, da localização de ossos e restos humanos e dos processos das famílias às voltas com o reconhecimento dos seus mortos. Ao lado dessa iconografia política do período da ditadura militar no país, não é difícil perceber também, no entanto, a quase exacerbação de um cotidiano marcado pela banalização da violência, da brutalização, exposto diariamente nas páginas policiais da imprensa brasileira. $\mathrm{E}$ com repercussão intensificada no caso de chacinas praticadas a mando dos grupos que dominam o tráfico de drogas nas grandes cidades brasileiras. Ou perpetradas pelas próprias forças policiais, como a de onze jovens em Acari, na Baixada Fluminense, em 1990, a de dez adolescentes assassinados no Morro de São Carlos em 1992, como o massacre de 111 detentos no pre- sídio do Carandiru, em São Paulo, no mesmo ano, como a execução de 21 pessoas em Vigário Geral, em 1993, de oito meninos de rua na igreja da Candelária, no Rio de Janeiro, também em 1993, de dezenove trabalhadores sem terra no município de Eldorado dos Carajás, no Pará, em 1996, ou como o assassinato de onze pessoas no Bar Ponto de Encontro, em Francisco Morato, em São Paulo, em 1998. Ocorrências que padronizam, via fotojornalismo, um tipo peculiar de iconografia corporal dolorosa, sublinhando a disseminação da violência, o aspecto cruento da história brasileira contemporânea.

Parecem combinar-se, então, desse ponto de vista, na refiguração em pedaços, em agonia, de personagens, retratos e narradores, na produção cultural brasileira recente, três ordens de fatores contextuais. De um lado, o diálogo com a fragmentação corporal característica à arte moderna e a um de seus pastiches, o Guignol. De outro lado, o registro indireto da experiência da tortura, das execuções, e da vivência política dos anos 1970. E, de outro lado, ainda, a convivência com o aumento do crime violento, das zonas de domínio do tráfico, e da violência também por parte das forças de segurança pública, durante as décadas de 1980 e 1990 no Brasil. Chamando a atenção, no entanto, o fato de, nessas tentativas de identificação cruenta dos sujeitos ficcionais, sua exposição não se ancorar em idealizaçôes subjetivas, imagens corporais coesas, de o processo mesmo de figuração e subjetivação envolver uma espécie de consciência necessária de sua instabilidade, um impulso concomitante, impositivo, de desfiguração, de guignolização.

Trata-se, no entanto, de uma desfiguração ambivalente. Pois se, por vezes, aponta para vitimizações, por vezes sobrepõem-se máscaras de agentes da violência a personagens, narradores e sujeitos poéticos, mantendo-se, com freqüência, igualmente, uma espécie de registro híbrido, no qual um misto de vítima e perseguidor é que move o processo de subjetivação literária. Daí, inclusive, a proliferação de híbridos, aberraçôes, figuras autodefinidas como 
monstros na literatura brasileira recente. E que, se em diálogo direto com um contexto particularmente cruento, apontam, via figuração monstruosa, para uma lacuna epistemológica, uma desestabilização classificatória, um confronto, na própria prática cultural, com os limites da expressividade e dos mecanismos de identificação, experimentados diante da afirmação de novas formas de organização das diferenças sociais em cidades pautadas simultaneamente numa homogeneização globalizadora do espaço e numa exacerbação do pânico da heterogeneidade social, na emergência de cidadelas autônomas fortificadas, na expansão da criminalidade violenta e de uma contínua violação dos direitos de cidadania justamente no contexto de uma redemocratização política em processo no país. Movimentos em meio aos quais é via vitimização e figurações proteicas, aberrantes, que parece possível engendrar retratos ficcionais, subjetividades literárias, representaçôes disformes da diferença, corpos culturais híbridos em estreita ligação com um processo histórico de redefinição de identidades e das formas de agenciamento social.

Não que as figurações monstruosas e animalizações da ficção contemporânea sejam unívocas. Observem-se, nesse sentido, as diferenças, por exemplo, entre, de um lado, o híbrido adolescente -braços compridos demais, pernas de avestruz, pêlos todos errados- do conto "Pequeno Monstro", de Caio Fernando Abreu, no qual se sobrepõem, nesse "pequeno, pequeno monstro, ninguém te quer", duas liminaridades, a da puberdade e a da descoberta da homossexualidade, e, de outro lado, o ritual de auto-canibalização de uma mulher em "Canibal", conto de Moacyr Scliar no qual a personagem se vê forçada a isso pela recusa de sua rica "irmã de criação" em compartilhar com ela de seu grande baú de alimentos, numa figuração exemplarmente cruel das divisões sociais em meio a aparente prosperidade econômica circunstancial.

O que parece estar em jogo, porém, nessas anomalias e zoologias ficcionais recentes, é o caráter inquietantemente próximo, nada exótico, de tais animais e monstruosidades. É o caso das "aberraçôes" propositadamente invisíveis de Bernardo Carvalho. Ou, no conto "Mandril" de Zulmira Ribeiro Tavares, da aproximação entre o jardim zoológico onde está o animal e um domingo numa sala com a televisão ligada num programa de calouros. Ou, movimento aparentemente inverso, como em Decálogo da Classe Média, nas figuraçōes horrendas da classe média por Sebastião Nunes, "cruzamento improvável de cigarras e formigas", órgãos genitais em proliferação, lagartos, insetos variados, crânios cheios de ratos, camaleões, cães, porcos, corpos tricéfalos, mas sempre em meio às atividades mais habituais, casamentos, reuniōes de trabalho, festas, exercícios esportivos. Ou, como nos contos de Nélson de Oliveira, cheios de "animais dos mais estranhos lugares", "criaturas aprisionadas", figuras assombradas, gente "movendo-se contra os próprios pés”, sonâmbulos, canibais, gente de "maneiras primitivas e mal formadas", "mais besta do que homem", monstros por vezes medonhos, que, no entanto, se dedicam ao mais corriqueiro, a telefonemas, cheques, cálculos, coisas do dia-a-dia. Numa espécie particularmente perversa de hibridização, entre o cotidiano e o bestial, entre a perversidade e a vitimização, a paralisia e a aniquilação. Daí a figura do dragão invencível capaz de transformar-se em qualquer um, dissolvendo qualquer possibilidade de auto-identificação, de diferenciação, no conto "Não sei bem o quê, aqui". Daí a impossibilidade de auto-reconhecimento da "pequena Victor" no belo conto "A Visão Vermelha”, do livro Naquela época tínhamos um gato. Daí o desaparecimento, pedaço a pedaço, do corpo do Sr. McPiffs, outro personagem de Nélson de Oliveira, semelhante ao de Angelina, a criatura "esguia e escura, de grandes olhos assustados", que se auto-devora no conto "Canibal", de Moacyr Scliar. Num movimento de instabilização da fronteira mesma do monstruoso, de refiguração lacônica do "não somos humanos" da G. H. do romance A Paixão segundo G. H. de Clarice Lispector. 


\section{Sebastião Uchoa Leite: a indeterminação identitária e os ruídos da polis}

Do ponto de vista da produção poética brasileira contemporânea, refiguraçōes animalizadas, híbridas, antifísicas, do eu, desdobramentos ambivalentes ou negativos do sujeito funcionariam como reforço de perspectivas antilíricas, dramatizações identitárias, conciliações rompidas entre voz e figura, e cumpririam papel particularmente crítico em trabalhos como o de Sebastião Uchoa Leite, por exemplo, no qual alter-representações subjetivas, "emaranhados do self", "línguas bífidas", ficções do eu se constituem em aspectos nucleares de uma negatividade metódica. Negatividade que, sobretudo nos seus livros mais recentes, e em diálogo evidente com circunstâncias médico-biográficas, envolveria uma reiterada exposição agônica do sujeito, freqüentemente em ambiente hospitalar, de que são exemplares a seção "Animal Máquina" de $A$ Uma Incógnita, os dez textos que compõem a seção "Incertezas" de A Ficção Vida e poemas como "Agulha" ou "Uma Voz do Subsolo" de A Espreita. Mas que tem nesse sujeito em agonia apenas uma das muitas ficções negativas do eu - "Eis-me: todos-os-eus/ euscatológico/ eucríptico/ eu-fim" - trabalhadas por Sebastião Uchoa Leite. E que vão de serpentes, "monstro/ enroscado em silepses", a vampiros, Drácula, Nosferatu, de heróis detetives a replicantes e a assassinos diversos, de "sr. Leite" a "um acuado joãocabral/ ou um valéry risível", de bogart, robert walker, yves montand, delon, montgomery clift a "barata sem antenas", "morcego de botequim", de "duplos metamorfoses monstros" a "resíduo de varredura/ que se recolhe/ com uma pá".

Disfarces, ocultações, trocas de identidade que convertem, com freqüência, os poemas de Sebastião Uchoa Leite em micro-narrativas policiais nas quais o elemento nuclear é ora um clima de generalizada suspeição, ora uma espécie de perseguição identitária - do sujeito, do poético-em-abismo. E não é à toa, nesse senti- do, que o poeta tenha se dedicado em Jogos e Enganos, uma de suas coletâneas de ensaios, ao estudo da "metáfora da perseguição", da estrutura e do repertório fundamental de variações do tema persecutório na cinematografia moderna e contemporânea. $\mathrm{O}$ que funciona como exercício auto-reflexivo, tendo em vista as cenas em sombras, a preferência pelo viés, pela sinuosidade, os disfarces e inversões de papéis, as formas de perseguição dominantes na sua poesia.

Por vezes o que domina é a perspectiva de um perseguido em fuga, como em "Vida é arte paranóica": "apenas correr/ alma de replicante/ até acertarem o plexo/ alvo perplexo". Por vezes a voz é de um perseguidor, de um poetaespiāo ou vampiro com "unhas em pique/ dentes em ponta". Por vezes o que se persegue é a própria poesia: "Precisamos/ de inteligências radar/ e sonar/ para captação de formas". Por vezes, com perspectiva distanciada, em terceira pessoa, é o sujeito mesmo do poema que se busca: "O não-herói busca o seu negativo:/ o seu dentro jack-the-ripper/ que não quisesse/ apenas matar./ Mas muito mais:/ ver de fora as tripas". Com freqüência, porém, como assinala Sebastiāo Uchoa Leite em "A Metáfora da Perseguição", "o que parece ser um território perfeitamente delimitado - de um lado o perseguidor e de outro o perseguido, de um lado a razão e de outro a não-razão - não o é jamais de um modo absoluto". Como se figura em "Os Assassinos e as Vítimas", poema no qual assassinos, detetives e perseguidores de todo tipo passam por uma inversão de papéis e se transformam em perseguidos por suas vítimas ou objetos de busca.

Além do intercâmbio de papéis, porém, forja-se um método poético pautado ele mesmo numa perspectiva ambivalente, a da espreita, que sugere tanto uma necessidade de esconderijo quanto um possível bote, tanto a expectativa de sofrer algum ataque, quanto de realização de alguma ação condenável. "Ali estou eu/ parado como se fosse um outro/ contratado para cometer um crime", lê-se em "Um Outro". "(Ele, em geral/ prefere enfiar-se/ no canto/ 
parado/ como uma víbora/ antes do bote/ observa/ calado/ o passar do tempo/ pelos relógios/ controlado/ passa pelas folhas/ do livro entreaberto/ o úmido índice do medo)", lê-se noutro poema de 1997. Trata-se, nos dois casos, de textos não à toa limitados por parênteses, num misto de ocultamento e suspensão, numa espécie de figuração gráfica da espreita. Em ambos os poemas pressentindo-se uma violência potencial, da qual o sujeito tanto pode ser o agente quanto a vítima.

A indeterminação identitária não se limitaria, porém, a essas figurações do sujeito, mas se espraiaria, igualmente, pelas relações entre as imagens do eu e as do espaço na poesia de Sebastião Uchoa Leite. Não à toa apontando para uma dissolução aquática mútua entre sujeito e paisagem na série de poemas sobre a chuva do livro A Espreita. De que é exemplar "Andando na Chuva: São José": "O meu eu-água/ autodissolvente/ cabelos/ pêlos/ olhos/ todos os poros/ entregues". Ou expondo-se - vide "Numa incerta noite" - uma contemplação de mão dupla, "vertigem inversa", entre o passante, "vendo a copa das árvores", e as folhagens e copas de árvores cujo "ciclópico olho vegetal" o contemplam nas ruas que atravessa. Não à toa assinalando-se, ainda, a perda dos limites entre dentro e fora, observador e cenário urbano, como em "Dentro/fora: Rio de Janeiro", onde "a rua pétrea/ de pedestres/ com pressa", vista "lá fora", "por trás dos vidros", parece deslizar "por dentro do vidro", vir "do outro lado da mesa". E chegando-se mesmo a atribuir à paisagem carioca uma das máscaras mais características do sujeito poético em Sebastião Uchoa Leite, a da serpente, transferida, em "O grande brilho", poema de 1991, para a baía de Guanabara: "Infusos no mar de amarelos/ Os focos verdes/ vermelhos/ Da enseada-serpente".

E, ao contrário da territorialização etnográfico-classificatória operada em geral pela ficção neodocumentalista dos anos 1990 , a produção de uma zona transicional entre dentro e fora, poeta e paisagem, na poesia de Sebastião Uchoa Leite, parece reduzir distâncias hierárqui- cas de observação entre sujeito e matéria urbana. Mesmo porque os papéis entre observador e observado, na sua obra, sempre podem se inverter. Não há um movimento de catalogação de figuras urbanas, excluídos, desabrigados, criminosos, como na literatura de testemunho, na prosa quase fotográfica das últimas décadas.

Pois se os quadros citadinos de Sebastião Uchoa Leite são percorridos por "in-seres", passantes "sob tendas de plástico azul", espécimes de uma "humanidade de cócoras", "sem-teto/ estáticos/ frente à multidão vil”, a perspectiva poética - sempre marcada por uma violência surda - não é hierárquica ou sistêmica, é oblíqua. Ou como se explica em "Exibicionistas e Voyeurs", poema de A Ficção Vida: "Voyeurs olham de viés". E, neste caso, seria possível acrescentar, por vezes trocam de papel. Como em dois poemas-anotaçôes de A Fiç̧ão Vida. Num deles, "O Sobrevivente", um sujeito observa "uma louca" que "discute consigo mesma/ Hamlet aos brados" e registra, via pronome pessoal, uma sobreposição entre observador e observada: "Este 'ser ali'/ Em alto regozijo/ Do meu perfeito juízo". Na outra anotação, "A obra lírica”, sobrepõem-se literalmente poema e fezes, pois a "obra" em questão resultava de um detrito urbano, de uma figura de cócoras defecando em plena rua Azeredo Coutinho, no Rio de Janeiro.

E é em parte por meio dessa constante possibilidade de cruzamento de fronteiras identitárias, sociais, espaciais que, apesar de Sebastião Uchoa Leite trabalhar regularmente com fios de enredo policial e tramas narrativas reconhecíveis, se intensifica o desconforto de um leitor exposto a zonas liminares, ambíguas, descontínuas, que se desdobram mesmo do ambiente mais cotidiano, e em meio a sinais imediatamente reconhecíveis do cenário urbano, como, no caso do Rio de Janeiro, a estátua do Cristo Redentor, o túnel que liga Botafogo a Copacabana, a Avenida Presidente Vargas. Num movimento de instabilização e desterritorialização, desconfortável do ponto de vista da recepção poética, e que, se em relação direta com a emer- 
gência de novas práticas urbanas, com a intensificação de uma segregação assimétrica do espaço social e de uma generalização da violência e da incivilidade diárias, não se limita a inventariar a experiência citadina brasileira. Fazendose dela elemento fundamental de indeterminação e negatividade estruturais, de um difícil processo de formalização literária que, no trabalho de Sebastião Uchoa Leite, se aproveita dos clichês da criminalização e os instabiliza em insólitos enfrentamentos e solidarizações entre o sujeito e "os ruídos da polis", e converte o topos moderno das caminhadas pela cidade, e suas tramas implícitas, em figuras mesmas de uma antilírica, de uma narratividade auto-corrosiva pautada numa quebra constante de versos e imagens, em "não-localidades” e num "jogo hiperrealista/ entre o eu e a margem".

Se, na poesia de Sebastião Uchoa Leite, a desterritorialização do cenário urbano se acha imbricada a toda uma série de trocas identitárias e desfiguraçôes, teria resultados poéticos distintos o recurso a procedimento semelhante por Ítalo Moriconi, em cujo livro Quase Sertão se forja uma figuração espacial híbrida - a de um deserto-cidade, por Angela Melim, cuja poesia é marcada por uma problematização recorrente do horizonte, ou por Duda Machado, em cujos poemas se tematiza o espaço como deriva, fuga à formalização, para ficar com apenas três exemplos significativos de um movimento de indeterminação nas figurações urbanas da poesia brasileira contemporânea. Movimento a que se poderiam acrescentar desde a janela que se fecha à visão da paisagem marinha, "de maneira a proscrever, velar a desfraldada/ tarde marinheira", do poema "Proscrição", à névoa em que se figura a baía, em "Enseada", também de Lu Menezes, da quase calçada inscrita no corpo - "rastro de mosca-bicheira/ imperceptível"- de um dos poemas de Fábrica, de Fabiano Calixto, ao horizonte "fora de qualquer perspectiva", à recorrência da imagem do deserto, passando por uma auto-figuração do sujeito como cacto, em Solo, de Ronald Polito.
E se, a rigor, o que chama a atenção é sobretudo a instabilização espacial, não faltam, a essas desterritorializaçôes, componentes cruentos. Do "sofrimento em festim", referido num dos poemas de Lu Menezes, ao corpo "blindado", em Ronald Polito, à "sensação de chumbo", ao "pé inoxidável” do trabalhador na fábrica, ao "corpo caído", "coagulada paisagem", no livro de Fabiano Calixto. Dos "arrastôes/chacinas megalópicas/infanticídios" ao "morto à bala", ao "inferno alighierico dos pobres", em Sebastiāo Uchoa Leite. Do "sopro de mortalidade dura”, em Quase Sertão, ao "varal/ atravessando a garganta/ o cômodo/ fio cego do punhal partindo o céu/ a privação/ no arame do cabide" no poema "Crente", de Angela Melim. Do "desejo de fuga", em "Giro", de Duda Machado, à "batalha/ travada em/ lugar algum", ao "não sei na madrugada/ se estou ferido/ se o corpo/ tenho/ riscado/ de hematomas" do poema "Mau Despertar", de Ferreira Gullar. Ou ao "eu sou pobre, pobre, pobre", ao "difere, fere, fere" do "Vers de circonstance", de Carlito Azevedo.

Os sinais de violência nessas figurações do urbano, se dizem respeito fundamentalmente ao próprio processo criativo, remetem, é claro, também, ao imaginário citadino contemporâneo, ao crescimento do crime violento e das reaçôes igualmente violentas a ele, à generalização da sensação de risco e de conflito potencial e à perda do sentimento de coletividade no cotidiano das grandes cidades brasileiras. Questôes que têm motivado um número igualmente crescente de estudos na área das ciências sociais no país. Por vezes com o privilégio da tensão entre redemocratização política e expansão dos crimes de sangue, duplicados, de acordo com Angelina Peralva, "entre 1980 e 1997 " e resultantes, a seu ver, de uma insegurança ampliada pela "interpenetração entre o universo dos morros e o da classe média”, pela "continuidade autoritária” e pela reestruturação das relações dominantes até o fim da ditadura militar "entre o Estado, o sistema político, a nação e a sociedade" (Peralva, 2000, p. 22, 59, 84 e 89). Já Teresa Pires do Rio Caldeira aponta, em Cidade de 
Muros, para essa contradição "entre expansão da cidadania política e deslegitimação da cidadania civil" e para o "caráter disjuntivo da democracia brasileira" como elementos nucleares de uma experiência urbana segregacionista, relacionando a criminalidade violenta não só à transformação das "configurações tradicionais de poder", mas à "deslegitimação do sistema judiciário como mediador de conflitos", à "privatização dos processos de vingança”, à "legalização das formas de abuso e violação de direitos" (Caldeira, 2000, p. 343). Ou, como enfatiza Luiz Eduardo Soares, a uma duplicidade constitutiva à organização social brasileira, a de uma sociedade orientada por elementos de um "modelo cultural hierárquico" e "socializada de acordo com o modelo cultural próprio ao individualismo igualitário liberal", a de um "projeto liberal-democrático" no contexto "de uma forte tradição nacional autoritária e excludente" (Soares, 2000, p. 34-6). Pois quando "são intensos os padrões de exclusão política e grande parte da população não se reconhece como partícipe de uma trajetória coletiva", como observa Maria Alice Rezende de Carvalho, "a cidade se torna objeto da apropriação privatista, da predação e da rapinagem, lugar onde prosperam o ressentimento e a desconfiança sociais" (Carvalho, s.d., p. 56).

Desse modo, torna-se problemática a percepção da cidade, e de suas figurações literárias, como unidades espaciais definidas, como espaços comuns de socialização. Ora expandindo-se "súbitos/ espaços", como em "Neste fio', de Régis Bonvicino, ora assistindo-se à sua intensa compressão, como nas "quatro paredes rentes", no "casulo/ compacto, nulo", no "espaço esparso" sugerido no livro Solo, de Ronald Polito. Ora desdobrando-se do urbano o deserto, como é o caso do "quase sertão" de Ítalo Moriconi, ou da "cidade deserta" mencionada em "Giro", de Duda Machado; ora privilegiando-se os "espaços-entre", as zonas de transição, como em Angela Melim. Com a diferença de, no caso dessas desterritorializações literárias, estar em pauta não apenas a forma urbana, mas um pro- cesso interno de formalização movido a orientações contraditórias. Apontando a indeterminação espacial, o geograficamente "informe", para a exposição de uma experiência formal marcada pela exacerbação das tensões entre horizonte e deriva, figuração e instabilização, persistência e dissipação.

\section{Ítalo Moriconi e a Cidade como Sertão}

A simples sobreposição do título Quase Sertão a reprodução fotográfica de paisagem nitidamente citadina, na capa da coletânea de poemas de 1996 de Ítalo Moriconi, já indica, via nomeação, a dominância de uma visualidade urbana, mas exposta a partir de um seu avesso potencial. Sem que, no entanto, o movimento proteico, a condensação das duas imagens de fato se efetive. Daí o advérbio, o "quase", responsável pela persistência das duas referências geográficas, da disparidade evocada por elas, por essa conjugação de cidade e sertão, acumulação e deserto. As imagens estruturais ao livro apontando simultaneamente para uma interseção de ambiências e para a impossibilidade de sua conciliação metafórica. A diferença, a conflitualidade latente entre elas, sugerindo uma amorfia metódica, um limite propositado - "palavra que falta", "meias-palavras" - nessa figuração urbana pelo avesso.

É evidente que as imagens do desértico, do silêncio, do áspero, da "vegetação esdrúxula, cheia de espinhos", de uma violência potencial, em meio a derivas, ruas, "carnavais", a uma "multidão sem face", a uma "chuva de figuras", "braços", "quadris", "carros retardatários", "prédios apagados", "calçadas", e a uma sucessão de caçadas amorosas anônimas - "ciscando no asfalto" -, emprestam à evocação do "sertão", nesse caso, a possibilidade de exposição das trilhas homoeróticas da cidade, da outra cidade embutida na cidade usual, na Av. Rio Branco, na Copacabana, na praia, nas esquinas de todos os dias. E de uma tensão recorrente entre o mais íntimo e o mais público, o sertão "mais pra den- 
tro" e o "excessivamente urbano". Entre os gânglios implodindo o pescoço e a lanchonete McDonald's em "(Notícia da AIDS)", "entre uma esquina e antigas angústias" em "Noturno", entre um "meu espaço", "meu olhar insolúvel", uma subjetividade e uma série de formas anônimas transitórias, "curvas fundas", "superfícies", "abismos", "vagas". Acompanhada de uma tensão de classe entre "o homem maduro e o rapaz das ruas", as referências cultas espalhadas nos poemas e os objetos de busca amorosa, definidos como "gente simples do povo". E entre uma espacialidade marcada pelo acúmulo "de tantos corpos", de ruas, prédios, esquinas, e a reiteração de imagens de um "esquema agreste", de um deserto, "imaginário plátano”, "terra oca, sem limites".

A referência ao sertão não se restringe, porém, nos poemas de Italo Moriconi, ao rastro de uma experiência urbana homoerótica. E parece apontar também para dualidades persistentes na vida literária brasileira, para as oposições e mediações entre cosmopolitismo e dado local, entre universalização e temática regional, litoral e interior. Dualidade latente, de modo quase irônico, na cidade que se dá a ler como agreste e no sertão emaranhado a formas urbanas; no sertão, imagem paradigmática de brasilidade, de uma geografia a céu aberto, com luz inclemente, e povoada, em geral, por jagunços e sobreviventes, mas convertido em oco da noite, paisagem privilegiada da deriva amorosa solitária de Quase Sertão. Um "oco" que define simultaneamente o trânsito pela cidade ("Nós dois e a rua. Nós dois, oco da noite.") e pelos corpos ("Flor do oco, broto espesso, lisura sem pêlos"), num desdobramento metafórico de um dos pólos da dualidade espacial que organiza todo o livro Quase Sertão. Espaço bifronte que serve de princípio de estruturação, por exemplo, a "Brinde", poema em diálogo com o "Boi Morto" de Manuel Bandeira, e no qual se opõem imagens do sertão-deserto ("há Nilo algum, planície ou deserto, só/ extenso como um traço que do silêncio flui"), e de uma possível configuração espacial definida, a uma deriva enumerativa ("arrastando no escuro/ correntes, martírios, pedaços de pau podre,/ espelhos e vidro partido e o resto"), uma "saudade cega/ em mar aberto, desconhecido, abandonado das esquinas".

E se o sertão já costuma se dar a ver simultaneamente tanto como vastidão, deserto, horizonte amplo, quanto como marcado por súbitos emaranhados vegetais, formas ásperas, raras, intrincadas, cactos, cerrado, sugerindo certa conflitualidade figurativa potencial, não é de estranhar que tenha servido de referência, na poesia de Ítalo Moriconi, para a exposição de imagens avessas, conflitivas, não apenas da paisagem urbana, mas da forma poética e do processo mesmo de composição. Pois é por meio de uma imagem cindida ("Tudo é conflito de figura no jardim de forças da rua sarcástica"), que é, de um lado, figura abstrata, desejo de "forma pura indivisa", "a forma, a forma das formas, o deserto", e, de outro, "deslocada em trancos, barrancos", "chuva de figuras", cidade, que se definem, em Quase Sertão, essas figurações espaciais, em disjunção interna, da experiência urbana e da forma poética.

Conflito imagético que, ligado à experiência histórica e as condições de produção literária no Brasil contemporâneo, envolveria, na poesia de Angela Melim, sobretudo desdobramentos e desfigurações do horizonte e uma ênfase metódica nas margens de indeterminação do espaço figurado, e que, no trabalho de Duda Machado, imbricaria deriva e forma, desejo construtivo e dissipação.

\section{Angela Melim e a dramatização do horizonte}

Se a reprodução de todas as capas dos seus livros anteriores, reunidos, em 1996, por Angela Melim em Mais Dia Menos Dia, funciona como marco divisório, modo de datar e singularizar as diferentes seçôes do volume, acaba apontando, igualmente, se observadas, com atenção, essas ilustrações, para uma das imagens 
privilegiadas da sua poesia - a do horizonte. $\mathrm{Da}$ linha horizontal irregular que atravessa o espaço inferior da capa de $O$ Vidro O Nome (1974), ao corte reto que separa em dois o título Das Tripas Coração (1978), ao corpo feminino que, deitado, parece duplicar o recorte das montanhas, ao fundo, na ilustração de capa de As mulheres gostam muito (1979), ao título em letras mínimas, quase imperceptível, disposto horizontalmente em meio a um vazio propositado de qualquer representação em Vale o Escrito (1981), aos barcos soltos na água, com apenas a sugestão de um limite possível, que quase se confunde com o recorte superior do papel mais grosso da capa em Os Caminhos do Conhecer (1981), ao espaço vazio, mais adiante, para o qual parece apontar a figura feminina estampada em $\mathrm{Po}$ emas (1987), ou, por fim, à ilustração de Nelson Augusto para Mais Dia Menos Dia (1996), na qual duas linhas e uma pequena mancha escura evocam a relação entre sujeito e paisagem, experiência poética e tematização do horizonte, e espacializam, numa linha-limite, a duração e a imagem de um tempo por vir sugerido no futuro potencial, quase próximo, do título.

"Estou procurando a palavra certa/ para partes superpostas de duas esferas/ Intersecção?/ E solidão": a indagação expressa em "Rabo de Galo", do livro de 1996, sublinha a preocupação de Angela Melim com os espaços limítrofes, transicionais, os "raros engates", os lugares-entre, a meio caminho, os horizontes. E há, na verdade, uma vasta sucessão de mares e céus na sua poesia. A água que "brilha, tranqüila, ao meio-dia", "azuis profundos versus altos mares", "azuis rasgados/ grandes paisagens/ claras", "um e outro coqueiro roxo contra o céu cor de rosa", "as linhas de água brilhante e as montanhas azuis um tanto esfumaçadas". Sucessão de horizontes atmosféricos e marinhos que, tendendo ao ilimitado, ao espelhamento dos "estados de alma", e parecendo reproduzir uma versão romântico-pitoresca da paisagem carioca, apontariam, no caso de Angela Melim, noutra direção.

Funcionam, de cara, como forma de recortar, nem que seja, às vezes, como fundo, a presença do mundo - "campo/verde/ minado", "montanha de cadáver", "ouvido violado, tímpano rompido/ braços cortados, cabeças"como elemento constitutivo da experiência poética. Tensionando-se, assim, via paisagismo, o modelo auto-referente, expressivo, dominante na produção poética brasileira dos anos 1970, contemporânea aos primeiros livros de Angela Melim. E, como sugere um texto como "Minha Terra", marcado pela visão em negativo da terra - "raízes no ar"- e do tema da "volta à casa", do enraizamento -"Nada é natal", tratase de um paisagismo em contraste direto com o descritivismo de molde romântico, que deixaria rastro na literatura brasileira subseqüente. Deste modelo descritivo se elimina, com freqüência, na poesia de Angela Melim, a fixidez do ponto de mira, exercitando-se formas diversas de objetivação e de distanciamento lírico, como em "Assim uma Linha Verde da Janela Um dia": "Assim uma linha verde da janela um dia/ átimo, repente - / correndo/ paralelo ao que é veloz/ colina/ planície/ estilete fino de metal/ no fundo". O "estilete fino" discreto, quase imperceptível, cumprindo função semelhante à do "campo/minado" do poema "Fogos Juninos" em termos de um desdobramento cruento de algo se assemelha a um simples quadro descritivo.

Ensaiam-se, igualmente, desdobramentos contrastantes de voz. Como entre a casualidade do sujeito que presta informaçôes para o viajante em "Roteiro", e o corte sistemático de sua fala por parênteses descritivos, impessoais e minuciosíssimos. Duplicidade que atinge também as figurações do espaço. Daí as transformaçôes - de diáfano, gaze, nuvem, a rosa bobo, baratopor que passa a idéia mesma de um céu cor-derosa em "No Céu Cor-de-Rosa" ou a definição móvel, em suspenso, de paisagem contida em "A Duna vira Nuvem, se quiser".

Não é, pois, exatamente enquanto extensão, infinito aberto ao olhar, ou limite fixo, contorno, que a imagem do horizonte parece orientar a escrita poética de Angela Melim. É sobretudo enquanto espaço-entre, zona de des- 
locamento, "exploração dos pontos cegos, das margens de indeterminação na linguagem e na paisagem" (Collot, 1988, p. 17), como assinala Michel Collot em L'Horizon Fabuleux, que ela tematiza e transporta, para o espaço poético, a noção de horizonte. $\mathrm{O}$ que, do ponto de vista da organização gráfico-sintática do poema explica a quantidade de brancos, intervalos, parênteses, travessões, estruturais nos seus textos, ou o gosto acentuado pelo verso isolado, solto, atravessando a página, cortando ou fechando alguns dos poemas à maneira de uma divisória, de uma linha interna do horizonte, muitas vezes intensificando um desdobramento ou um conflito de liminaridades. Como na frase longa que, em "O Mar não Existe", depois de cinco versos curtos, internaliza um mar de ausência e impossibilidade numa espécie de horizonte orgânico em corrosão: "A acidez é um fogo comendo o tubo escuro que atravessa o corpo". Como no caso de "Ronca um motor", de Mais Dia, Menos Dia, o verso "É o verão que se abre", que, separado dos demais por dois espaços em branco, parecendo sintetizar, via destaque gráfico, as imagens anteriores de barco, mar, calor, e figurar uma extensão paisagístico-temporal "a céu aberto”, se faz acompanhar, no entanto, de um outro horizonte, conflitante, que inverte não só o seu movimento de ampliação, mas a referência temporal a um período que começa, transformando-se a gênese de um verão em imagem de um passado próximo à dissolução: "Tarde, sorvete, amor/ varanda/ em taças do passado/ a derreter".

A consciência do horizonte na poesia de Angela Melim, em vez de suporte espaço-temporal ou ponto de orientação da perspectiva subjetiva, aponta, portanto, para um movimento de sistemático redimensionamento mútuo do sujeito e da paisagem, de que é exemplar a reflexão sobre a morte contida em "Limão Irmão", na verdade o simples registro de uma fruta que cai e rola pela terra, "que agora traga/ a carne aberta/ desesperada/ do limão". E de que é exemplar, igualmente, sua preferência pelo intervalar, pelas linhas que figuram e desfigu- ram o espaço e a escrita, por uma espécie de dramatização do horizonte, desdobrado em formas diversas, mas obrigatórias, de conflito e indeterminação.

"E ela gostaria", lê-se em "Os Caminhos do Conhecer", "de pintar as unhas de vermelho. Enquanto escrevesse as palavras no caderno ia prestar atenção nos dedos de pontas brilhantes segurando a esferográfica e sentir prazeres conflitantes". Movimento semelhante ao que, entre um "lá dentro" e um "pé de jasmim”, em "Mulheres", entre um "à flor da pele" e um "fosso fundo", em "Faca na água", entre "cristas suspensas/ pedras de sal/ fiapos de mar" e "seu fundo longínquo/ âncora/ os leitos de areia e seus lençois limpíssimos", em "Um Navio", figura "janelas", "lagos no peito", "navio", imagens de fronteira, espécies de não-lugares. A que se poderiam acrescentar a bainha, o varal, a beira-mar, a fresta, a aresta, o vão, as grades, a beira, de tantos outros poemas seus, nos quais se tensionam e convivem essas direções conflitantes. Ou que, em meio a uma sucessão de marinhas e paisagens à primeira vista pouco habitadas, quase desistoricizadas, ativam uma espécie de conflito surdo, quase imperceptível, entre quadro natural e horizonte histórico. Entre um exercício lírico em torno de sol, flores e perda, como "Corajoso como a Beleza”, e sua sucessão de imagens bélicas: disparos, bala, dor, estrondos, combate. Entre "os ladrilhos/ o verde baço do cloro/ a piscina" e o "arame" que a resguarda, em "Álbum", o "cheiro/ do jasmim" e um "sangue vivo/ a pena contido", o "céu azul e limpo" e "granadas", "fogo, fumaça", em "Fogos Juninos". Ou entre o horizonte da cidade e o da escrita, em "Trilha", com a mediação de um terceiro horizonte, bélico, de "cerco, baixas, barranco, armas", que parece redimensioná-los historicamente.

\section{Duda Machado e a deriva metódica}

Já os poemas de Duda Machado, se igualmente marcados por uma exposição conflitiva do espaço, parecem movidos por um princípio de 
contra-organização, por uma indeterminação metódica, mas variada, que, de dentro, os desdobra e reengendra, apontando para uma forma poética propositadamente instável, em fuga, não à toa figurada, repetidas vezes, por imagens marcadas exatamente pelo movimento, pela transparência e pela tendência ao informe, à desterritorialização, como as do vento e da onda, fundamentais à auto-explicitação de uma poética pautada na modulação ("quem reina?/ uma modulação/ capaz de afinar/ o entendimento"), na tensão entre desgarre e condensação, deriva e desejo de fixação ("brisa/ ainda há pouco formada,/ a confluência/ entre passagem e morada"), dominantes em Margem de uma onda (1997), seu livro mais recente.

Há, no entanto, desde $Z i l$, uma recorrência dessas imagens aéreas, aquáticas, móveis. Da associação do livro ao rio, no texto inicial deste volume de 1977, ao "mar/ na ponta dos cascos" de "Verão", às vogais "líquidas, cascateantes, enchentes", ou às imagens de vôo, os mandacarus revoando, em "Ária", ou poema-pergunta sobre o que soaria mais alto, se "o vôo ou o canto do pássaro". Imagens em movimento dominantes igualmente no seu segundo livro, Um Outro (1990).Como nos seus diversos percursos, alvos em movimento, na multidão definida como "moinhos de braços", na chuva que segue a moça, na ciclista que passa, e na colocação em roda até mesmo das "idéias fixas", exemplo quase paradoxal da poética eólia, instável, de Duda Machado.

Ventos, vôos, moto contínuo se acham contrastados, porém, em Um Outro, a uma indagação, também recorrente, sobre a margem, o horizonte, o limite, do acontecimento, da linguagem, ou entre "contemplador, céu e mar", "céu e asfalto", "jardim e tarde", "morte-vida”. Entre um desejo de contorno, recorte, formalização, e por uma espécie de hesitação das formas, de desmaterialização inevitáveis. "A vida,/ sem medida/ e isto/, rigor", lê-se no segundo poema de Um Outro. "O horizonte", expõe a primeira estrofe de "Juntos", "é a luz/ que em cor tão unânime/ apaga as superfícies/ de que vive". Assim como, no turvo espelho interior, lê-se em "Tanto Ser", "desfiguram-se os atos" e o corpo se mostra "impalpável, carcaça/ que o espírito não acha”.

Em Margem de uma onda, essa tensão entre movimento de formalização e de dissipação, de figuração e iminente desfiguração, tematizada, de modos diversos, em todo o livro, daria lugar à poética singular exposta em "Fábula do Vento e da Forma", "Manhã Piscina" e "Margem de uma onda", em parte em diálogo com "Imitação da água", de João Cabral de Melo Neto. Nela estabelecendo-se, a princípio por negação, uma analogia entre o vento e a forma, elementos a rigor incompatíveis, em irredutível desacordo, de um lado, pelo desejo de persistência próprio à forma, de outro lado, pelo aspecto passageiro próprio ao vento. Em ambos os casos, porém, o percurso diverso sinalizaria no sentido de uma correspondência, pelo avesso, entre essas diferenças, que seria levadas à própria mútua negação. Do lado da forma, ativando-se um processo de múltiplo desdobramento em metamorfoses. Do lado do vento, por conta da possibilidade de subitamente tomar forma, caso o seu movimento se opere, por exemplo, "sobre a harpa eólia/ ou nos móbiles de Calder", como sublinham os dois últimos versos do poema.

O curioso, no caso dessa fábula, estando não só no "desacordo uníssono" em que ela se baseia, mas no fato mesmo de as duas imagens se encaminharem necessariamente para o próprio esgotamento. à maneira do que se dá com a voz que "se recolhe" em "Interferência", a cor que "cai sobre si mesma" em "Aventura da Cor", os detalhes "moldados pela desagregação" em "Poética do Desastre", a "fadiga" que "a cada coisa/ desdobra e dissipa" em "Dentro do Espelho", o quarto que, "depois de condensar/ tempo e espaço", se concentra na janela e encontra o vácuo e "os limites da calçada/ embaixo" em "Resumo quase abstrato". Não sendo de estranhar, ainda, em meio a essa sucessão de dissoluções e a ameaça de auto-anulação embutidas nas imagens dominantes de tantos desses poemas, 
que alguns deles se convertam, ao contrário, em genealogias da forma, como "Traço e Movimento", "Fragmentos para Novalis", "Condição" ou "À Noite na Estrada". Ou que forma e deriva se apresentem explicitamente geminadas num poema como "Trevo": "uma imagem à deriva/ tão densa/ em seu ensimesmamento // a ponto de excitar/ o desejo de forma/ até esgotá-lo/ e reafirmar sua deriva/ várias oitavas acima".

E, dado fundamental ao método poético de Duda Machado, não se trata, no seu caso, simplesmente de uma reflexão sobre a indeterminação, mas de um processo de composição tensionado internamente, ele mesmo, e não apenas suas imagens, por negatividade e resistência estruturais à unificação formal. Tensionamento interno manifesto tanto por meio do recurso recorrente às enumerações (de que são exemplares os seus dois "Almanaques") ou a imagens contraditórias ("e a $40^{\circ}$, uma tristeza de inverno"), quanto via recortes repentinos do poema: uma outra voz (como na terceira estrofe de "Fala" ou na metade de "Corte e Costura”), um pontilhado (como em "Álbum”), um intervalo (como entre o "Psiu" e o resto de "Fantasma Camarada"), uma troca de registro (como entre a impessoalidade das seis primeiras estrofes e a intimidade dos dois últimos versos de "Oração com Objetos"), uma interrogação (como os versos entre parênteses de "Margem de uma onda").

Tensionamento manifesto igualmente, na poesia de Duda Machado, pela irrupção, em meio às figuras aéreas e dissipações formais, de imagens de extrema concretude, quase brutais: o mendigo de "Flores de Flamboyant", as cenas de perseguição, revista e fuzilamento de "Fim de Semana", os passageiros de ônibus convertidos num híbrido indistinto em "Carapicuíba", a desova e as crianças-carniças de "Urubu-Abaixo". Numa operação figurada pelo próprio poeta em "Devoração da Paisagem". Aí, a uma primeira estrofe a rigor tranqüilizadora, com uma simples descrição de vista - com casas, morro, arvoredo, estrada e riacho -, se seguem três desterritorializações. A primeira no sentido de uma expansão - "cores que ultrapassam distâncias", "o olhar que erra e se prolonga/ em busca de sua moradia”. A segunda no sentido de um desdobramento de ponto de mira, de uma contração da paisagem - "de algum lugar,/ distante das retinas,/ a fera irrompe". A terceira exibindo a paisagem presa, relatando a sua devoração. E apontando para a sugestão de uma espécie de impossibilidade histórica e formal da paisagem e de figurações espaciais incruentas.

Daí a sobreposição esgarçada - "quase" de sertão e cidade na poesia de Ítalo Moriconi, o desdobramento conflitivo de horizontes em Mais Dia Menos Dia, de Angela Melim, as indeterminações identitárias em Sebastião Uchoa Leite, a contra-formalização convertida em princípio ativo de composição em Duda Machado. Exercícios distintos de desterritorialização e irrepresentabilidade espacial que, por via negativa, conflitiva, parecem, ao contrário, contribuir para a intensificação da percepção do momento presente e ampliar a própria investigação formal ao interseccionar a prática poética aos desdobramentos históricos recentes de uma experiência urbana violenta, segregacional, autoritária, como a brasileira. 


\section{Referências bibliográficas}

ABREU, Caio Fernando. Os dragões não conhecem o paraíso. São Paulo: Companhia das Letras, 1988.

. Ovelhas negras. Porto Alegre: Sulina, 1996.

AZEVEDO, Carlito. Sob a noite fisica. Rio de Janeiro: Sette Letras, 1996.

CALDEIRA, Teresa Pires do Rio. Cidade de Muros. Crime, Segregação e Cidadania em São Paulo. São Paulo: Editora 34/EDUSP, 2000.

CALIXTO, Fabiano. Fábrica. Santo André: Alpharrabio, 2000.

CARRERO, Raimundo. As sombrias ruinas da alma. São Paulo: Iluminuras, 1999.

CARVALHO, Bernardo. Aberração. São Paulo: Companhia das Letras, 1993.

CARVALHO, Maria Alice Rezende de. "Violência no Rio de Janeiro: uma reflexão política". In: Pereira et alii (org.). Linguagens da Violência.

COLLOT, Michel. L’ Horizon Fabuleux. Paris: Librairie José Corti, 1988.

CONTI, Mário Sérgio. "Encontros Inesperados” (Entrevista com Ismail Xavier). In: Mais!. Folha de S. Paulo, 3/12/2000, p. 8-9.

FELINTO, Marilene. Mulheres de Tijucopapo. 2a ed. São Paulo: Editora 34, 1992.

FERREZ. Capão Pecado. São Paulo: Labor Texto Editorial, 2000.

FONSECA, Rubem. Contos reunidos. São Paulo: Companhia das Letras, 1994. . O buraco na parede. São Paulo: Companhia das Letras, 1995.

FREIRE, Marcelino. Angu de Sangue. São Paulo: Ateliê Editorial, 2000.

Inimigo Rumor. Revista de Poesia. N. 3. "Dossiê Ferreira Gullar”. Set-Dez. 1997.

LEITE, Sebastião Uchoa. "A Metáfora da Perseguição". In: Jogos e enganos. Rio de Janeiro/São Paulo: Editora UFRJ/Editora 34, 1995. - A Espreita. São Paulo: Perspectiva, 2000. . A Ficção Vida. São Paulo: Editora 34, 1993. . A uma incógnita. São Paulo: Iluminuras, 1991. . Obra em Dobras. São Paulo: Duas Cidades, 1988.

LINS, Paulo. Cidade de Deus. São Paulo: Companhia das Letras, 1997. MACHADO, Duda. Margem de uma onda. São Paulo: Editora 34, 1997. MELIM, Angela. Mais dia menos dia. Rio de Janeiro: Sette Letras, 1996. MELO, Patrícia. Acqua Toffana. São Paulo: Companhia das Letras, 1994. MENEZES, Lu. Abre-te, Rosebud!. Rio de Janeiro: Sette Letras, 1996.

NOLL, João Gilberto. Romances e Contos reunidos. São Paulo: Companhia das Letras, 1997.

NUNES, Sebastiāo. Decálogo da classe média. Sabará: Ediçōes Dubolso, 1998. 
OLIVEIRA, Nélson. Naquela época tínhamos um gato. São Paulo: Companhia das Letras, 1998. . Treze. São Paulo: Ciência do acidente, 1999.

Ortiz, Esmeralda do Carmo. Por que não dancei. Org. de Gilberto Dimenstein. São Paulo: Senac, 2000.

PERALVA, Angelina. Violência e Democracia: o paradoxo brasileiro. São Paulo: Paz e Terra, 2000.

POLITO, Ronald. Solo. Rio de Janeiro: Sette Letras, 1996.

SANTIAGO, Silviano. Cheiro Forte. Rio de Janeiro: Rocco, 1993.

SCLIAR, Moacyr. Contos reunidos. São Paulo: Companhia das Letras, 1995.

SILVA, Hélio R. S. \& MILITO, Cláudia. Vozes do Meio-Fio. Rio de Janeiro: Relume-Dumará, 1995.

SOARES, Luiz Eduardo. "Uma Interpretação do Brasil para contextualizar a violência". In: PEREIRA, C. A. M.; RONDELLI, E.; SHOLLHAMMER, K.-E. \& HERSCHMANN, M. (orgs.). Linguagens da Violência. Rio de Janeiro: Rocco, 2000.

TAVARES, Zulmira Ribeiro. O Mandril. São Paulo: Brasiliense, 1991.

VARELLA, Drauzio. Estação Carandiru. São Paulo: Companhia das Letras, 1999.

VÁRIOS. Letras de Liberdade. São Paulo: Madras, 2000.

XAVIER, Ismail. “O cinema brasileiro dos anos 90” (entrevista). In: Praga. Estudos Marxistas, n. 9. São Paulo: Hucitec, 2000.

XAVIER, Valêncio. "Minha história dele”. In: Ficçôes. Ano 1, n. 1. Abril, 1998. 